\title{
PRIORITAS ASPEK-ASPEK TIPOLOGI LINGUISTIK PADA PEMETAAN MASALAH-MASALAH KEBAHASAAN
}

\author{
Mirsa Umiyati \\ Universitas Warmadewa \\ mir_zha78@yahoo.co.id
}

\begin{abstract}
Abstrak
Tulisan ini memberikan tinjauan teoretis mengenai kajian tipologi linguistik yang dibedakan dari kajian tipologi bahasa secara struktural yang selama ini lebih akrab di kalangan linguis. Fokus penjabaran teoretis dimaksud adalah penjabaran prinsip-prinsip kerja kajian tipologi linguistik sampai dengan jabaran aspek-aspek tipologi linguistik bahasa Lokal di Indonesia yang diprioritaskan untuk dikaji. Instrumen penjaringan data lapangan, proses identifikasi sampai pemetaan masalah pada aspek ini juga dijabarkan untuk memberi jawaban dari suatu pertanyaan, Bagaimana paradigma teori tipologi linguistik melihat bahasa sebagai objek dan bagaimana melakukan penelitian pada tipologi linguistik pada bahasa manusia untuk mencapai keuniversalan bahasa? Jabaran pemetaan masalah ranah ini juga disertai dengan jabaran solusi dan strategi menjawab pemetaan masalah-masalahnya. Pada akhirnya, tulisan ini menyimpulkan suatu rumusan tentang kontribusi kajian tipologi linguistik dalam mendesain riset proses dan produk aspek kebahasaan terutama bahasa-bahasa lokal di Indonesia.
\end{abstract}

Kata Kunci: tipologi bahasa, tipologi linguistik, prinsip dan parameter keuniversalan.

\begin{abstract}
This paper provides an overview of the theoretical study of linguistic typology which is distinguished from structural study of language typology that had been more familiar among linguists. The focus of theoretical elaboration in question is the translation of the principles of linguistic typology study work until the elaboration of aspects of linguistic typology local languages in Indonesia are prioritized for review. Instruments crawl field data, the identification process until the mapping problem on this aspect are also elaborated to give an answer to a question. How is the paradigm theory of linguistic typology see language as an object and how to conduct research on linguistic typology on achieving the universality of the human languages?. The descriptions of Mapping problem domains. It is also accompanied by the elaboration of solutions and strategy mapping problems. This paper formulates a definition of the contribution of linguistic typology studies in research design process and product aspects of language, especially in Indonesian local languages.
\end{abstract}

Keywords: language tipology, linguistic typology, principle and parameter of universality.

\section{PENDAHULUAN}

Dengan jumlah kuantitatif bahasa di dunia yang sangat fantastis menurut SIL yaitu 6703 bahasa di dunia (Grimes, 1996), maka kajian tipologi bahasa menjadi cabang ilmu linguistik yang tepat untuk membedah dan menyelidiki bahasa-bahasa di dunia dimaksud. Bila diperhatikan, keragaman bahasa-bahasa lokal yang ada di
Indonesia, kajian tipologi linguistik akan menjadi magnet tersendiri yang sangat menarik untuk dijadikan landasan teori untuk membedah sejumlah masalah-masalah kebahasaan yang ada. Yang harus digarisbawahi adalah, kajian tipologi tidak dapat dipisahkan dari ilmu bahasa secara umum dan ilmu linguistik secara khusus. Meskipun demikian, kajian tipologi linguistik 
harus dipisahkan dari kajian tipologi bahasa yang memiliki penekanan yang berbeda.

Satu hal yang harus dicatat adalah, meskipun bahasa-bahasa di dunia pasti memiliki perbedaan-perbedaan, pasti ada properti-properti tertentu yang membuat bahasa-bahasa di dunia dikenali dalam satu kategori bahasa manusia. Oleh karena itu, pasti ada suatu kesatuan yang mendasari bahasa manusia. Ada linguis yang secara langsung mencurahkan perhatiannya untuk mengungkap kesatuan ini dengan mempelajari variasi struktural yang sangat banyak ditemukan dalam bahasa-bahasa dunia.Para linguis ini dikenal sebagai ahli tipologi linguistik. Penyelidikan yang para ahli ini lakukan terhadap variasi antarbahasa disebut tipologi linguistik, atau tipologi. Contohnya, setelah mengamati eksistensi dari keenam urutan dasar yang mungkin secara logika dalam bahasabahasa di dunia, para ahli tipologi linguistik akan mengajukan pertanyaanpertanyaan seperti: bagaimana distribusi nyata dari keenam urutan kata dasar dalam bahasa-bahasa di dunia?, apakah setiap urutan kata dasar didistribusikan secara merata ke dalam bahasa-bahasa di dunia?, jika tidak, apakah frekuensi dari setiap urutan kata dasar?, dan urutan kata dasar yang mana yang paling banyak atau sedikit terdapat pada bahasa-bahasa dunia?. Hal ini menunjukkan bahwa pendistribusian urutan -urutan kata dasar seharusnya paling tidak didistribusikan secara merata diantara bahasa-bahasa di dunia, sekitar 16,6\% untuk setiap urutan kata dasar yang ada.

Lebih lanjut, para ahli tipologi linguistik membandingkan dua atau lebih properti-properti struktural dengan pandangan untuk menentukan apakah ada suatu hubungan (penting menurut statistik) antara properti-properti ini dan, jika ya, seberapa kuat hubungan itu. Contohnya, urutan kata dasar telah dibandingkan dengan kemunculan (atau ketiadaan) preposisi-preposisi, atau posposisi.Bahasabahasa yang dimulai dengan verba (atau bahasa -bahasa yang verbanya berada pada posisi pertama dalam kalimat, seperti VSO dan VOS) selalu dilengkapi dengan preposisi-preposisi, bukan dengan posposisi. Ini berarti bahwa susunan kalimat yang diawali dengan verba tidak terjadi bersamaan dengan posposisi.

Penemuan ini berisi satu properti penting bahasa manusia dimana properti itu mewakili batasan pada variasi yang mungkin terjadi dalam suatu bahasa: tidak ada bahasa yang diawali dengan verba yang diprediksi memiliki posposisi. Tidak ada alasan mengapa dua properti independen yaitu urutan kata dasar serta kemunculan preposisi atau posposisi berhubungan dengan asumsi bahwa hadirnya urutan kata dasar yang diawali verba mengimplikasi- 
kan kemunculan preposisi. Secara logika, seharusnya ada pula bahasa-bahasa yang berawalan verba muncul bersama posposisi, yang bukan merupakan kasus itu.Pertanyaan yang secara langsung dihadapi oleh para ahli tipologi linguistik adalah, apakah korelasi semacam itu benarbenar ada.

Dalam istilah yang lebih umum, tugas utama untuk para ahli tipologi linguistik adalah untuk mengidentifikasi dan menjelaskan properti-properti yang membuat bahasa manusia seperti apa adanya. Pertanyaan itu juga dapat disampaikan dengan cara yang berbeda: apakah yang dimaksud dengan bahasa manusia yang mungkin, yang berlawanan dengan tidak mungkin? Tetapi, seperti yang telah didemonstrasikan berkaitan dengan pendistribusian urutanurutan kata dasar (yaitu enam kemungkinan yang logis tentang urutan kata ditunjukkan pada tingkatan yang berbeda dalam bahasabahasa di dunia), para ahli tipologi linguistik mungkin juga menyampaikan sebuah bentuk yang ringan atau sederhana atas pertanyaan itu: apakah yang dimaksud dengan bahasa manusia yang lebih mungkin, berlawanan dengan yang kurang mungkin?

\section{KERANGKA TEORETIS}

Secara etimologis, tipologi berarti pengelompokan ranah (classification of domain). Pengertian tipologi bersinonim dengan istilah taksonomi (Mallinson dan Blake, 1981:3). Istilah teknis tipologi yang telah masuk ke linguistik mempunyai pengertian yang merujuk ke pengelompokan bahasa-bahasa berdasarkan ciri khas tatakata dan tatakalimatnya. Mallinson dan Blake (1981:3) mengatakan bahwa bahasa-bahasa dapat dikelompokkan berdasarkan batasan-batasan ciri khas strukturalnya. Mereka juga menyebutkan bahwa tipologi yang terkenal adalah tipologi yang berusaha menetapkan pengelompokan luas berdasarkan sejumlah fitur yang saling berhubungan.

Di antara bentuk kajian tipologi periode awal dalam linguistik adalah tipologi tataurutan kata (word order typology) seperti yang dilakukan oleh Greenberg (1963) (lihat Mallinson dan Blake, 1981). Kajian tipologi Greenberg telah menunjukkan bahwa bahasa-bahasa dapat dikelompokkan menurut urutan dasar subjek, objek, dan verba $(\mathrm{S}, \mathrm{O}, \mathrm{V})$. Kajian yang berusaha mencermati fitur-fitur dan ciri khas gramatikal bahasa-bahasa di dunia kemudian membuat pengelompokan yang bersesuaian dengan parameter tertentu dan dikenal dalam dunia linguistik sebagai kajian tipologi linguistik (linguistic typology) atau kajian tipologi bahasa (language typology).

Artawa (2013) mengemukakan bah- 
wa dalam beberapa buku rujukan, istilah tipologi linguistik dan tipologi bahasa kadang-kadang dipakai dalam pengertian yang sama. Jika dicermati lebih jauh, kedua istilah tersebut sesungguhnya mempunyai pengertian yang berbeda. Tipologi linguistik, di satu sisi, merujuk ke teoriteori atau kerangka teoretis tipologi yang dikenal dalam linguistik. Tipologi linguistik dapat dikatakan sebagai teori yang dijadikan dasar pengkajian untuk mengelompokkan

bahasa-bahasa berdasarkan parameter tertentu. Di sisi lain, tipologi bahasa berarti kelompok-kelompok bahasa yang kurang lebih mempunyai ciriciri dan sifat perilaku gramatikal yang sama. Sehubungan dengan itu, tipologi bahasa merupakan hasil pengkajian berdasarkan teori tipologi linguistik.

Istilah tipologi linguistik juga sering mempunyai pengertian yang sama dengan linguistik tipologi. Perbedaan kedua istilah ini hanyalah pada penekanannya. Tipologi linguistik mempunyai pengertian sebagai teori atau kerangka teoretis suatu bentuk kajian dalam linguistik yang menjadikan tipologi sebagai penekanannya; kajian pengelompokan (tipologi) dalam dunia linguistik. Jika disebut linguistik tipologi, penekanannya adalah pada linguistiknya; teori-teori atau model pengkajian linguistik untuk menemukan tipologi bahasa. berbicara tentang tipologi linguistik tataurut kata (Greenberg), tipologi linguistik Mallinson dan Blake, tipologi linguistik Comrie, tipologi linguistik Dixon, dan lain sebagainya. Meskipun teori tipologi linguistik itu dikemukakan oleh banyak ahli (untuk memudahkan, penyebutannya dikaitkan dengan nama ahli yang mengembangkannya), namun tujuan utama ilmu tipologi linguistik tersebut pada dasarnya adalah sama. Comrie (1988) menyatakan bahwa tujuan linguistik tipologi adalah untuk mengelompokkan bahasa-bahasa berdasarkan sifat-perilaku struktural bahasa tersebut. Tujuan pokoknya adalah untuk menjawab pertanyaan: seperti apa bahasa x itu? Ada dua asumsi pokok linguistik tipologi, yakni: (a) semua bahasa dapat dibandingkan berdasarkan strukturnya; dan (b) ada perbedaan di antara bahasa-bahasa yang ada.

Berdasarkan pengkajian teori tipologi linguistik tersebut, para ahli berupaya melakukan pengelompokan bahasa-bahasa yang melahirkan tipologi bahasa. Bahasabahasa dapat dikelompokkan menjadi bahasa bertipologi akusatif, ergatif, atau aktif. Dengan demikian, istilah bahasa akusatif, bahasa ergatif, atau bahasa aktif merupakan sebutan tipologi untuk bahasabahasa yang kurang lebih (secara gramatikal) mempunyai persamaan (lihat Comrie, 1989; Dixon, 1994; Artawa, 1998; 
Djunaidi, 2000b). Pentipologian bahasabahasa berdasarkan sifat-perilaku gramatikal tersebut untuk lebih jelasnya sering pula disebut sebagai kajian tipologi gramatikal. Penyebutan ini dilakukan untuk membedakannya dari kajian tipologi fungsional yang mendasarkan pentipologian bahasa-bahasa secara pragmatis atau berdasarkan fungsi bahasa sebagai alat komunikasi. Dengan demikian, dalam perkembangannya, tipologi linguistik dapat dibedakan menjadi tipologi gramatikal dan tipologi fungsional (Artawa, 1998; Jufrizal, 2004; Givon, 1984, 1990).

Comrie (1988b) menyatakan bahwa tujuan linguistik tipologi adalah untuk mengklasifikasikan bahasa-bahasa berdasarkan properti struktural bahasa-bahasa tersebut. Tujuan pokoknya adalah untuk menjawab pertanyaan : Seperti apakah bahasa X? Kajian linguistik tipologi, menurut Comrie (1988b), mempunyai dua asumsi pokok, yaitu (a) diasumsikan bahwa semua bahasa dapat dibandingkan berdasarkan strukturnya, (b) diasumsikan juga bahwa ada perbedaan di antara bahasa-bahasa yang ada. Bahasa umumnya dibedakan menjadi bahasa yang bertipe akusatif, ergatif, dan akif.

\section{ANALISA TIPOLOGIS}

Untuk mencapai tahapan bertanya dan dengan harapan menjawab pertanyaan yang diajukan pada akhir bagian sebelumnya, para ahli tipologi linguistik harus melewati empat tahapan berikut ini dalam analisa tipologis: (i) identifikasi atas sebuah fenomena yang dipelajari; (ii) klasifikasitipologis terhadap fenomena yang sedang diselidiki; (iii) formulasi dari (a) generalisasi atas klasifikasi yang dibuat; dan yang terakhir (iv) penjelasan dari generalisasi tersebut.Pertama, para ahli tipologi linguistik harus menentukan apa yang akan mereka selidiki. Tentu saja, tidak ada batasan teoritis atas properti-properti struktural apa atau fenomena gramatikal apa yang sebaiknya atau tidak boleh diteliti. Juga tidak ada pembatasan mengenai berapa banyak properti yang harus diteliti secara simultan pada waktu yang telah diberikan. Beberapa ahli tipologi linguistik mungkin memilih satu fitur bahasa sebagai sebuah objek penelitian, sedangkan yang lainnya mungkin memilih lebih dari satu bahasa dalam satu kali penelitian.

Seorang ahli tipologi linguistik harus berhati-hati dalam menentukan properti -properti mana yang dipilih untuk analisa tipologis sehingga benar-benar layak untuk diteliti dibandingkan dengan sejumlah properti yang lebih menarik atau lebih dikenal dibandingkan properti lainnya. Dengan kata lain, sejumlah properti lebih memungkinkan dibandingkan lainnya untuk mengarah pada generalisasi- 
generalisasi tipologis yang penting secara linguistik. Contohnya, bandingkan properti tipologis dari urutan kata dasar dengan munculnya pertanyaan. Seperti yang telah ditunjukkan, seleksi dari urutan kata dasar sebagai sebuah properti tipologis telah mengarah pada sejumlah besar pertanyaan dan masalah yang menarik baik secara teori atau empiris.

Bagaimana bila bahasa-bahasa di dunia akan dibagi dalam dua tipologi: Grup pertama dengan bentuk pertanyaan, dan yang satu lagi tanpa bentuk pertanyaan. Apa yang harus dipahami dari klasifikasi tipologis yang biasa ini? Tampaknya tidak banyak lagi yang harus dilakukan atau dipelajari tentang itu. Sulit untuk membayangkan bahwa klasifikasi tipologis ini banyak digunakan untuk memahami hakekat dari bahasa manusia - kecuali klasifikasi ini barangkali diteliti berkaitan dengan beberapa properti struktural lainnya. Oleh karena itu, dalam satu hal, tahap pertama dari analisa tipologis mungkin tergantung pada intuisi atau penghayatan sang peneliti secara krusial sampai pada sebuah tingkatan yang besar seperti halnya dalam jenis usaha ilmiah apapun. Lebih lanjut, tahap pertama dan kedua dari analisa tipologis mungkin telah dilaksanakan pada waktu bersamaan sampai pada sebuah tingkat tertentu. Hal ini dikarenakan seseorang tidak mengetahui terlebih dahulu apakah properti yang dipilih akan menjadi sebuah properti yang signifikan secara tipologis atau tidak.

Ketika sebuah properti (atau sejumlah properti) telah dipilih untuk analisa tipologis, tipe-tipe struktural sesuai dengan properti (atau properti-properti) itu akan diidentifikasi atau dirumuskan sehingga bahasa-bahasa di dunia pada akhirnya dapat digolongkan ke dalam tipe-tipe tersebut. Dalam kasus urutan kata dasar, sebagai contoh, enam tipe (yang mungkin secara logika) diidentifikasi, dimana bahasabahasa dibagi dalam tipologi menurut tipe urutan kata dasar yang ditunjukkan. Sejumlah bahasa akan dikelompokkan sebagai SOV, yang lainnya VSO, dan begitu seterusnya. Identifikasi dari enam tipe urutan kata dasar, serta penggolongan bahasabahasa dunia ke dalam tipe-tipe tersebut akan membentuk tipologi linguistik urutan kata dasar. Pendistribusian yang tidak merata dari keenam urutan kata dasar yang muncul dari penggolongan tipologis ini disimpulkan sebagai sebuah kecenderungan yang berbeda terhadap SOV, dan SVO dalam bahasa-bahasa dunia. Hal ini kemudian digunakan sebagai generalisasi yang penting atas tahap (iii) di atas yang mewakili data terklasifikasi. Pendistribusian ini pada akhirnya juga akan mengarah ke pertanyaan tentang mengapa ada kecenderungan kuat seperti tahap (iv). Pada tahap terakhir 
ini, para ahli tipologi linguistik akan mencoba untuk menjelaskan kecenderungan struktural yang dipertanyakan.

Komentar-komentar serupa dapat dibuat untuk melihat korelasi antara urutan kata yang diawali verba, dan preposisipreposisi, yang telah ditunjukkan di bagian 1.1.Pertama, bahasa-bahasa dunia diamati berdasarkan urutan kata dasar pada satu sisi, dan adanya (atau tidak adanya) preposisi atau posposisi pada sisi lainnya. Ada empat kombinasi logis berbeda dari 2 properti ini (2x2): (i) bahasa-bahasa yang berawalan verba beserta preposisi-preposisi; (ii) bahasa-bahasa yang berawalan verba beserta posposisi (misal, non-preposisi); (iii) bahasa-bahasa yang tidak berawalan verba beserta preposisi (misal, medialverba atau final verba); dan terakhir (iv) bahasa-bahasa yang tidak berawalan verba beserta posposisi. Bahasa dunia kemudian akan digolongkan menjadi empat tipe. Hasilnya, semua tipe tersebut kecuali yang ada dalam (ii) direpresentasikan dengan baik dalam bahasa-bahasa di dunia seperti yang diilustrasikan oleh contoh-contoh berikut

(1) Tzotzil (VOS \& prepositions)
a. ?i-s-pet
lok'el ?antz ti t'ul-e
CMP-3-carry away woman the rabbit-CLT
'The rabbit carried away the woman.'
b. xchi?uk s-malal
with 3-husband
'with her husband'

(2) Yoruba (SVO \& prepositions)

a Bàbá ra bàtá

Father bought shoese

Father bought shoese.'

b. Ńí ojà

At market

'at the market'

(3) Canela-Kraho (SOV \& postpositions)

(a). Hũmre terop cakwĩn

man PST dog beat

'The man beat the dog.'

(b) Pu kam

field in

'in the field' 
Penggolongan ini akan meningkat menjadi generalisasi: keberadaan urutan kata yang berawalan verba mengimplikasikan munculnya preposisi. Sebaliknya hal ini akan membutuhkan suatu penjelasan tentang mengapa hubungan implikasional ini muncul diantara urutan kata yang berawalan verba dengan preposisi.

\section{ASUMSI-ASUMSI DAN MASALAH- MASALAH DALAM ANALISA TI- POLOGIS}

Sedikitnya ada dua asumsi teoritikal yang harus dibuat dalam analisa tipologis: cross-linguistic comparability dan uniformitarianism. Selain itu, sedikitnya ada dua masalah praktis bahwa para ahli tipologi linguistik harus menyampaikan dan jika mungkin, membuat pernyataan-pernyataan tegas tentang bagaimana mereka akan menghadapi atau yang telah mereka hadapi dalam penyelidikan tipologis bahasa. Ini adalah masalah-masalah language sampling dan data collection. Paling tidak, tampak bahwa ketika kedua asumsi secara logika dianggap tidak kontroversial, masalahmasalah pengambilan sampel bahasa dan pengumpulan data jauh dari kepastian, masalah pengambilan sampel bahasa telah menarik perhatian para ahli tipologi linguistik selama bertahun-tahun.

PENDEKATAN-PENDEKATAN UN-

\section{TUK PENGAMBILAN CONTOH BA-}

\section{HASA}

Secara intuisi, cara terbaik untuk mengungkap keuniversalan bahasa barangkali dengan meneliti seluruh bahasabahasa dunia. Namun, untuk alasan-alasan yang jelas, sangat mudah untuk melihat mengapa mustahil untuk melakukan hal itu. Seperti yang kami tunjukkan di awal bab ini, ada sekitar 4.000 sampai 7.000 bahasa yang saat ini diucapkan di dunia. Para ahli tipologi linguistik yang bersifat individu (atau bahkan sebuah tim dari para ahli tipologi linguistik) tidak mampu membandingkan bahasa-bahasa yang begitu banyak dan membuat mereka tertarik. Ternyata, benar-benar mustahil untuk meneliti semua bahasa-bahasa dunia karena banyak bahasa yang telah punah, dimana hanya sebagian dari bahasa-bahasa itu yang meninggalkan sedikit catatan atau tidak sama sekali, meskipun keberadaan bahasabahasa tersebut kita ketahui (misal, bahasa Arin, Assan, Kassitic, Illyrian, dan lainlain). Mungkin ada banyak juga bahasa yang bahkan tidak diketahui kalau bahasabahasa itu pernah ada. Selanjutnya, dengan dialek-dialek yang berkembang dalam bahasa-bahasa yang berbeda sepanjang masa, akan ada juga bahasa 'baru' yang muncul. Jika tujuan seseorang adalah untuk meneliti semua bahasa di dunia, maka harus ada tempat untuk bahasa-bahasa baru ini dalam 
penelitiannya.

Menurut batasan waktu, dana, eksistensi dan deskripsi (Perkins 1989: 297), para ahli tipologi linguistik sering bekerja dengan rangkaian bahasa-bahasa yang dapat dikelola secara praktis atau apa yang biasa disebut sebagai sebuah sampel bahasa. Pada dasarnya, pertanyaan-pertanyaan yang muncul adalah mengenai berapa banyak bahasa yang harus dimasukkan ke dalam sampel tertentu, dan bagaimana bahasa -bahasa harus diseleksi untuk sampel tersebut. Beberapa peneliti selama bertahuntahun telah menyampaikan hal ini serta pertanyaan-pertanyaan terkait lainnya tetapi tampaknya beberapa dari pertanyaan itu 'sayangnya tetap tak terjawab' (Croft 1995: 89).

Bell (1978) adalah yang pertama kali mengangkat masalah pengambilan contoh bahasa untuk penelitian tipologi. Dalam karyanya yang sangat berpengaruh, ia menjelaskan peranan dari penggolongan dalam pengambilan sample bahasa (yaitu, proses penempatan bahasa ke dalam strata yang berbeda, misal, afiliasi genetik, lokasi geografis, tipe urutan kata, dan lain-lain) dan mendiskusikan penyimpanganpenyimpangan genetik, wilayah dan bibliografi yang harus dihindari dalam pengambilan sampling bahasa.

Pertama, pembahasan Bell mengarah pada keuntungan metodologis utama dari pemakaian sampel-sampel bahasa. Seperti yang ditunjukkan oleh Perkins (1989: 300) secara tepat, pengambilan sampel bahasa memiliki dua syarat saling bertentangan yang harus dipenuhi. Sebuah sampel bahasa harus memiliki sebanyak mungkin bahasa sehingga kesimpulankesimpulan atau generalisasi-generalisasi apapun yang didapat dari sampel itu dapat diperluas ke dalam bahasa pada umumnya dengan sebuah cara empiris. Pada saat yang bersamaan sampel bahasa itu harus memiliki sedikit mungkin bahasa karena itulah ide utamanya menggunakan sampel itu terlebih dahulu. Berkaitan dengan persyaratan kedua ini adalah resiko memasukkan lebih banyak bahasa setiap strata dari yang dibutuhkan, sehingga memperkenalkan 'variabel-variabel yang tidak independen dari afiliasi genetik dan lokasi'. Dalam sampel-sampel yang digolongkan jumlah kasus yang diteliti bisa dikurangi dalam jumlah besar daripada jumlah kasus yang dibutuhkan dalam tipe-tipe sampel lainnya. Ini menunjukkan dengan kuat bahwa seseorang paling tidak secara prinsip dapat mempelajari sifat bahasa manusia dari sebuah sampel dengan sedikit bahasa sebanyak yang didapat dari sebuah sample dengan banyak bahasa (Perkins 1989:298).

Yang sama pentingnya adalah fakta bahwa penggolongan dalam pengambilan contoh bahasa paling tidak secara prinsip 
memastikan bahwa bahasa-bahasa yang dipilih harus independen, dan 'bukan kasus -kasus yang identik yang seharusnya lebih tepat dianggap sebagai contoh-contoh yang berbeda dari kasus yang sama' (Perkins 1980: 60-61; 1992:124). Ini dikenal sebagai masalah kemandirian kasus yang sepertiakan terlihat sekarang ini, mungkin telah menjadi masalah yang paling sulit yang harus dihadapi oleh para ahli tipologi linguistik dalam pengambilan contoh bahasa.

Bell (1978:127-9, 137-40) juga menekankan pentingnya probabilitas atau pengambilan contoh secara acak. Penggunaan probabilitas atau pengambilan contoh secara acak tidak hanya memudahkan peneliti untuk menjalankan beragam pengujian untuk memastikan apakah penemuan mereka penting menurut statistik (atau apakah mereka mempunyai kesempatan). Tetapi penggunaan probabilitas juga membuatnya mungkin 'untuk mengukur besarnya kesalahan dari sebuah sampel yang sederhana' (Bell 1978:157). 'Mengevaluasi resiko [dari kesalahan pengambilan contoh] yang terlibat dalam perbedaan-perbedaan dari sebuah sampel sampai pada populasi dari semua bahasa sangatlah diinginkan dalam memastikan ketepatan hasil-hasil yang diperoleh dalam sebuah pengujian khusus sebuah teori' (Perkins 1980: 59-60; 1992:127). Sebagai contoh, pastinya Tomlin (1986: 25-
6), mampu untuk memilih 'sampel terbaik dari sejumlah sampel yang potensial secara tepat karena dia menggunakan jenis teknik pengambilan contoh probabilitas yang digolongkan ini.

Kedua, Bell (1978:145-149) membutuhkan sampel-sampel bahasa untuk menjadi perwakilan dari distribusi nyata bahasa-bahasa di dunia secara akurat.Untuk mencapai sebuah perwakilan sampel semacam itu seseorang harus berupaya mengatasi penyimpangan-penyimpangan pengambilan contoh tertentu. Secara spesifik disebutkan bahwa penyimpanganpenyimpangan genetik dan wilayah harus dieliminasi dari sampel-sampel bahasa. Bahasa-bahasa dari sebuah keluarga bahasa tunggal memiliki properti-properti struktural atau fitur-fitur yang sama dengan yang berkualitas baik dan telah diambil dari sumber yang sama. Bahasa-bahasa ini ditakdirkan untuk memiliki propertiproperti struktural dari orang tua atau leluhur mereka.Selain itu, bahasa-bahasa dari akar-akar genetik yang berbeda juga diketahui membagi properti-properti struktural atau fitur-fitur ketika bahasabahasa ini telah lama saling berhubungan. Dengan kata lain, fitur-fitur struktural mungkin hadir untuk membongkar batasanbatasan dari seluruh genetik yang berdampakdimana bahasa-bahasa ini dibagi oleh aneka bahasa yang tidak saling berhub- 
ungan atau paling tidak berasal dari kelompok kecil yang berbeda dalam sebuah keluarga. Wilayah pertemuan bahasa semacam ini secara teknis disebut sebuah wilayah bahasa atau Sprachbund. Sebagai contoh, bahasa Meso - America dilaporkan sebagai sebuah contoh Sprachbund yang baik (Campbell, Kaufman dan Smith-Stark 1986).

Ada sejumlah fitur-fitur dari bahasa -bahasa di luar wilayah itu: misal, kepemilikan nomina; penggunaan nominanomina penghubung; sistem bilangan vigesimal; urutan kata dasar akhir non verba; beberapa terjemahan semantik yang tersebar luas; dll. Masing-masing properti yang dibagikan oleh bahasa-bahasa yang berkaitan dengan warisan genetik umum atau hubungan merupakan apa yang disebut 'kesempatan' atau properti-properti struktural yang tak terencana dari kelompok-kelompok bahasa atau area-area bahasa (Comrie 1989:10). Properti-properti ini harus dibedakan secara hati-hati dari properti-properti yang sungguh-sungguh mewakili keuniversalan bahasa, dan tidak harus dianggap sebagai karakteristik dari bahasa manusia.Oleh karena itu, perlakuan khusus harus dilakukan untuk memastikan bahwa kelompok-kelompok bahasa tertentu tidak terwakili secara berlebihan (atau kurang-terwakili) dalam sampel-sampel bahasa, tetapi bahasa -bahasa itu diseleksi dengan benar dari semua kelompokkelompok bahasa yang dikenal. Seandainya seseorang ingin meneliti konstruksi klausa relatif pada lintas bahasa.

Bila sebuah sample tertentu mengandung terlalu banyak bahasa-bahasa Eropa yang dihasilkan dari kelompokkelompok atau keluarga-keluarga bahasa lainnya, maka penggunaan pronomina pronomina relatif akan menjadi kepentingan atau penekanan tertentu yang lebih banyak dari seharusnya dalam penelitian seseorang karena seperti yang telah kita bahas terlebih dahulu, penggunaan pronominal-pronominal relatif sering dijumpai dalam bahasa-bahasa Eropa dan ternyata jarang ditemui dalam bahasa-bahasa dunia lainnya. Generalisasi apapun yang diambil dari sampel itu pada akhirnya akan mengalami representasi berlebihan dari bahasabahasa Eropa, serta perkiraan berlebihan dari tipe pronomina relatif dalam teori universal tentang konstruksi-konstruksi klausa relatif. Sebalikya, bila sebuah kelompok bahasa kurang terwakili dalam sebuah sampel tertentu, maka ini berarti bahwa properti-properti struktural yang berkaitan dengan kelompok bahasa itu akan sebaliknya dianggap kurang penting dari semestinya, dan kelompok-kelompok bahasa lainnya juga akan berakhir menjadi terwakili secara berlebihan-bahkan bila itu hanya untuk membuat ukuran yang belum ditentukan 
dari sampel tersebut. Terlalu banyak bahasa yang berasal dari sebuah Sprachbund tunggal juga bisa dimasukkan ke dalam sebuah sampel, dimana ada sebuah resiko salah penafsiran karena properti-properti struktural keuniversalan bahasa yang merupakan karakteristik dari Sprachbund itu.

Bahaya ini tampak semakin besar ketika seseorang menghadapi sebuah wilayah bahasa yang muncul jauh lebih besar dari yang biasa diketahui. Contohnya, diyakini secara luas bahwa dahulu ada sebuah kecenderungan bahasa untuk bahasabahasa O (byek-) V (erba) untuk menempatkan adjektiva-adjektiva pemodifikasi (atau A) sebelum nomina (atau N). Namun, Dryer 91989: 274 - 5) menemukan bahwa korelasi yang diakui antara OV dan AN berkaitan sekali dengan fakta bahwa ini merupakan pola yang dominan dalam bahasa Eurasia-yang biasanya tidak terpikirkan untuk membentuk sebuah Sprachbund. Dryer menunjukkan bahwa kecenderungan dalam bahasa-bahasa dunia, ternyata merupakan pola yang berbeda yaitu OV dan NA. Jadi representasi berlebihan atas bahasa-bahasa Eurasia harus diamati secara hati -hati terhadap pembuatan sampel-sampel bahasa.

Para ahli tipologi linguistik seringkali mendapatkan diri mereka sendiri dalam situasi yang tidak menyenangkan dimana mereka dipaksa untuk memilih baha- sa-bahasa untuk sebuah sampel, yang sangat tergantung pada ada tidaknya deskripsideskripsi gramatikal atau tatabahasa. Tentu saja ini merupakan sebuah situasi yang tidak menguntungkan tetapi kadang-kadang tidak dapat dihindari. Sebagai contoh, bahasa-bahasa Indo-Eropa terdokumentasi dengan sangat baik menurut keluasan dan kedalamannya, sementara cakupan bahasabahasa dari New Guinea dan Amerika Selatan sangat kurang. Bahkan jika para ahli tipologi linguistik ingin memasukkan sejumlah bahasa-bahasa yang mewakili dari bahasa-bahasa New Guinea atau Amerika Selatan dalam sampel-sampel mereka, para ahli ini mungkin tidak akan bisa mempunyai sejumlah akses yang cukup ke bahasa-bahasa tersebut karena sebelumnya tidak ada cukup tata bahasa yang tersedia dari bahasa-bahasa di daerahdaerah ini. Hal ini merupakan sesuatu yang tidak mudah untuk diperbaiki, dan akan terus berlanjut untuk menciptakan sejumlah distorsi atau ketegangan tertentu dalam sampel-sample milik para ahli tipologi linguistik 'bahkan disaat eksistensi dari ketidak-seimbangan dan kerugiannya dikenali [sic]' (Comrie 1989:11).

Para ahli tipologi linguistik mungkin juga bekerja di suatu tempat dimana tatabahasanya telah terpublikasikan sehingga tidak dapat dijangkau oleh mereka; contohnya, perpustakaan-perpustakaan yang 
mereka andalkan hanya memiliki bahasabahasa Indo-Eropa atau Oseanik dan sedikit lainnya. Ini apa yang Bell (1978:145) sebut sesungguhnya sebagai penyimpangan bibliografis. Bila penyimpangan semacam ini tak terhindarkan dan ada dalam sebuah sampel, maka paling tidak yang dapat dilakukan oleh seorang peneliti adalah menyatakan secara terbuka eksistensi dari masalah itu demi kepentingan para linguis lainnya.

Untuk alasan-alasan sebelumnya yang pragmatis, para ahli tipologi linguistik seringkali memilih apa yang disebut convenience atau opportunity samples (Bell 1978: 128). Mereka mungkin hanya menyeleksi bahasa-bahasa yang mereka kenal atau yang memiliki akses melalui deskripsi gramatikal atau konsultan-konsultan bahasa. Ternyata, sejumlah besar karya-karya tipologis yang inovatif berdasarkan sampel -sampel kemudahan semacam itu (misal, Greenberg (1963b); Comrie (1976); Keenan dan Comrie (1977); Nichols (1986) inter alia). Kelemahan-kelemahan terlihat jelas dalam sampel-sampel mereka meskipun mereka tidak hanya memberikan banyak pemahaman pada sifat bahasa manusia, yang terus memainkan sebuah peranan penting dalam penelitian tipologis. Tetapi, seringkali, mereka juga memberikan kekuatan untuk penelitian yang berskala besar selanjutnya. Tidak perlu dikatakan, generalisasi atau kesimpulan apapun yang berdasarkan sampel-sampel kemudahan semacam itu harus dianggap apa adanya - petunjuk-petunjuk atau penemuan-penemuan sebelumnya yang berkaitan dengan pola-pola lintas bahasa, atau keuniversalan bahasa - dan generalisasi atau kesimpulan itu harus mengalami verifikasi empiris lebih lanjut, atau revisi yang berdasarkan pada lebih banyak bahasa, atau sampel-sampel bahasa yang dibuat lebih layak.

Bagaimana bahasa-bahasa kemudian dapat diseleksi dengan benar dari seluruh kelompok-kelompok bahasa di dunia? Bell (1978:145-9) mengemukakan sebuah usulan khusus mengenai bagaimana hal ini dapat dicapai.Ia membuat sebuah rentang waktu yang terkontrol secara acak dari keterkaitan genetik selama3.500 tahun sehingga semua bahasa-bahasa dunia dapat masuk ke dalam sejumlah kelompokkelompok genetik yang dapat menentukan batasan, yang ternyata berjumlah total 478 kelompok. Sebagai contoh, kelompok bahasa Indo-Eropa dianggap berisikan dua belas grup, sedangkan bahasa Australia mempunyai sekitar dua puluh tujuh grup. Penggunaan rentang waktu yang terkontrol dari 3.500 tahun, meskipun acak, ditujukan bukan pada tingkatan yang kecil untuk merefleksikan perbedaan genetik dalam keluarga bahasa, atau kelompok bahasa 
(Bell 1978: 146).Semakin banyak kelompok-kelompok genetik dalam keluarga bahasa atau kelompok bahasa, semakin banyak pula perbedaan yang ditunjukkan oleh keluarga atau kelompok bahasa tersebut. Contohnya, menurut perhitungan Bell, bahasa Niger-Kordofanian, dan bahasa Amerind masing-masing berisikan 900 bahasa.Tetapi perbedaan genetik dari dua simpanan ini tidak dapat diperbandingkan, dimana bahasa Niger-Kordofanian tidak terlalu rumit secara genetis dibandingan dengan bahasa Amerind. Kelompok bahasa Niger Kordofanian berisikan 44 grup, sedangkan kelompok bahasa Amerind diperkirakan berisikan 150 grup.

Oleh karena itu, mustahil, untuk benar-benar terbebas dari variabel-variabel sampel yang besar atau faktor-faktor yang tergantung pada afiliasi genetik atau lokasi geografis.Pada kenyataanya, Dryer (1989: 263) melangkah lebih jauh untuk menunjukkan bahwa tidaklah mungkin untuk membuat sebuah sampel lebih dari sepuluh bahasa dari banyak bahasa bila seseorang memutuskan untuk bersikap tegas mengenai indepedensi kasus-kasus dalam pengambilan contoh bahasa (tetapi lihat Perkins (1989: 308)). Tentu saja, sebuah sampel dari sepuluh bahasa sepertinya tidak akan menghasilkan generalisasigeneralisasi penting apapun mengenai sifat dari bahasa manusia.
Singkatnya, dalam sampel-sampel kecil dimana beberapa kelompok bahasa tidak dipertimbangkan, indepedensi kasuskasus yang dibutuhkan dari pengambilan contoh statistik tidak terjaga karena bahasabahasa mungkin saling tergantung satu dengan yang lainnya, dengan beberapa dimasukkan ke dalam, dan yang lainnya dikeluarkan dari sampel akhir. Juga dalam kasus sampel-sampel yang besar, bahasabahasa yang dipilih mungkin tidak independen, dimana beberapa terhubung jauh satu dengan yang lainnya atau berasal dari wilayah bahasa yang sama. Oleh karena itu, baik validitas, dan ketergantungan dari kesimpulan-kesimpulan yang didapat dari sampel-sampel akan dikompromikan seperlunya jika indepedensi kasus-kasus tidak ditegakkan dengan tegas dalam membuat sampel-sampel tersebut.

Sembilan ratus bahasa dalam keluarga bahasa itu tersusun dengan pola SVO, dan seluruh bahasa dari sepuluh keluarga bahasa lainnya merupakan SOV. Seperti yang ditanyakan oleh Dryer, apakah kita menyimpulkan dari pendistribusian ini bahwa ada preferensi bahasa untuk SVO terhadap SOV? Tentu saja tidak. Justru kita akan sampai pada kesimpulan bahwa SOV mewakili sebuah preferensi bahasa dalam urutan kata dasar. Dasar dari kesimpulan itu sangat jelas.Fakta bahwa 900 bahasa dari 1000 bahasa adalah SVO hanya merupakan 
sebuah kesalahan sejarah non-bahasa. Sembilan ratus bahasa ini merupakan SVO karena, sebagai contoh, bahasa-bahasa ini harus telah mewarisi urutan kata dasar yang sama dari bahasa induknya. Ada 10 keluarga SOV yang berhadapan hanya dengan satu keluarga SVO. Perbedaan antara preferensi bahasa dan frekuensi -frekuensi nyata dari tipe-tipe bahasa adalah sesuatu yang penting, yang seringkali tidak dikenali dan dibuat dalam kepustakaan tipologis. Merupakan hal yang menarik untuk mengambil kesimpulan dari perbedaan itu bahwa tidak ada preferensi linguistik untuk SOV dan pengesampingan SVO.

\section{STUDI KASUS}

Dalam penjabaran studi kasus aspek-aspek tipologi linguistik yang menjadi prioritas untuk dikaji, dideskripsikan studi kasus penipologian suatu Bahasa $\mathrm{X}$ berdasarkan perilaku adjekitvanya dan bukan perilaku verba bahasa $\mathrm{X}$ sebagai kelas kata utama dalam kategorisasi kelas kata. Umiyati (2013) merumuskan tipologi Bahasa sebagai berikut:

\section{(1). Aspek Rumusan Perilaku Gramat-}

\section{ikal Adjektiva BI}

Dengan mencermati keseluruhan

(ii)

A $<=>$ C. $1 \rightarrow$ PERILAKU VERBA MENYERUPAI ADJEKTIVA

$\mathrm{B}<=>$ C. $1 \rightarrow$ PERILAKU NOMINA MENYERUPAI ADJEKTIVA

$\mathrm{C}<=>$ C. $1 \rightarrow$ PERILAKU ADJEKTIVA MURNI pembahasan yang ditunjang oleh buktibukti empiris seperti telah dikemukakan di atas, diketahui bahwa (1) fungsi gramatikal verba berterima pada verba, dan pada sebagaian adjektiva (sebagian adjektiva yang lain, (a) tidak bisa berfungsi predikatif atau (b) bisa namun bersyarat); (2) Fungsi gramatikal adjektiva, selain berterima pada dirinya sendiri, juga berterima diemban oleh verba dan nomina sedangkan (3) Fungsi gramatikal nomina, selain nomina itu sendiri, hanya adjektiva yang dapat menempati fungsi yang sama (baik dalam ([a] proses nominalisasi maupun [b]sebagai leksem tunggal), sedangkan verba tidak pernah bisa. Dari ilustrasi tabel di atas juga dapat disimpulkan bahwa properti verba berterima pada verba dan adjektiva, namun properti nomina tidak berterima untuk verba dan adjektiva. Sedangkan properti adjektiva berterima pada ketiganya. Secara lengkap rumusan perilaku dimaksud adalah sebagai berikut.

(i) Jika A adalah adjektiva; $\mathrm{B}$ adalah nomina; $\mathrm{C}$ adalah verba; $\mathrm{A} 1$ adalah perilaku gramatikal adjektiva; B1 adalah perilaku gramatikal nomina dan $\mathrm{C} 1$ adalah perilaku gramatikal verba, maka 
$\mathrm{C}<=>$ A. $1 \rightarrow$ PERILAKU ADJEKTIVA MENYERUPAI VERBA

$\mathrm{B}<=>$ A. $1 \rightarrow$ PERILAKU NOMINA MENYERUPAI VERBA

$\mathrm{A}<=>$ A. $1 \rightarrow$ PERILAKU VERBA MURNI

$\mathrm{C}<=>$ B. $1 \rightarrow \neq($ TIDAK PERNAH TERJADI $)$

$\mathrm{A}<=>$ B. $1 \rightarrow \neq($ TIDAK PERNAH TERJADI)

$\mathrm{B}<=>$ B. $1 \rightarrow$ PERILAKU NOMINA MURNI

(ii). Jika D adalah properti verba dan D1 adalah perilaku gramatikal verba; Jika E adalah properti nomina dan E1 adalah per- ilaku gramatikal nomina; Jika $\mathrm{F}$ adalah properti adjektiva dan F1 adalah perilaku gramatikal adjektiva maka:

(iii)

$\mathrm{E}<=>$ D. $1 \rightarrow$ PERILAKU NOMINA MENYERUPAI VERBA (Bersyarat)

$\mathrm{F}<=>$ D. $1 \rightarrow$ PERILAKU ADJEKTIVA MENYERUPAI VERBA (hanya pada sebagian adjektiva)

$\mathrm{D}<=>$ D. $1 \rightarrow$ PERILAKU VERBA MURNI

$\mathrm{D}<=>$ F. $1 \rightarrow$ PERILAKU VERBA MENYERUPAI ADJEKTIVA

$\mathrm{E}<=>$ F. $1 \rightarrow$ PERILAKU NOMINA MENYERUPAI ADJEKTIVA

$\mathrm{F}<=>\mathrm{F} .1 \rightarrow$ PERILAKU ADJEKTIVA MURNI

$\mathrm{F}<=>$ E. $1 \rightarrow$ PERILAKU ADJEKTIVA MENYERUPAI NOMINA

$\mathrm{D}<=>$ E. $1 \rightarrow \neq($ TIDAK PERNAH TERJADI $)$

$\mathrm{E}<=>$ E. $1 \rightarrow$ PERILAKU NOMINA MURNI

\section{(2). Aspek Tipologi Properti Gramatikal}

\section{Adjektiva}

Secara lintas bahasa, Dixon (2010) telah merumuskan tipologi perilaku gramatikal adjektiva lintas bahasa berdasarkan kepemilikan dan atau keberterimaannya atas sejumlah properti gramatikal. Hasil rumusan dimaksud membagi adjekitva dalam 4 (empat) kelompok bahasa, sebagai berikut.

(1). Adjektiva yang menunjukkan properti gramatikal yang sama dengan verba

(2). Adjektiva yang menunjukkan properti gramatikal yang sama dengan nomina

(3). Adjektiva yang menunjukkan properti gramatikal yang sama dengan nominanamun dan verba

(4). Adjektiva yang mempunyai properti gramatikal yang berbeda dari verba dan nomina .

Keempat jenis tipologi bahasa tersebut dirangkum dalam tabel berikut (kemiripankemiripan tata bahasa serta perbedaanperbedaan antara kelas-kelas kata yang dicontohkan oleh jarak spasial).

Tabel 7.1 Rangkuman Jenis Tipologi Bahasa

\begin{tabular}{|l|l|l|l|l|l|l|l|}
\hline BHS.A & NOMINA & & & & & ADJ & VERBA \\
\hline BHS.B & NOMINA & ADJ & & & & & VERBA \\
\hline BHS.C & & & NOMINA & ADJ & VERBA & & \\
\hline BHS.D & NOMINA & & & ADJ & & & VERBA \\
\hline
\end{tabular}


Dari keempat kelompok bahasa tersebut, adjektiva BI tidak menunjukkan perilaku yang mengarahkannya masuk dalam satu kelompok tertentu karena data empiris menunjukkan bahwa adjektiva BI terinfleksi properti gramatikal verba namun tidak menunjukkan keberterimaannya atas properti gramatikal nomina. Satu-satunya keberterimaan adjekitva BI atas nomina adalah keberterimaannya terinfleksi aturan sintaksis nomina. Aturan sintaksis dimaksud berupa aturan gender dan penanda jumlah yang terealisasi dalam bentuk reduplikasi untuk menyatakan bentuk jamak atau plural. Dengan demikian, adjektiva BI tidak dapat dimasukkan dalam salahsatu dari 4 (empat) tipe Bahasa, yaitu bahasa $A$, bahasa $B$, bahasa $C$ dan bahasa $\mathrm{D}$.

Berdasarkan penjabaran di atas, diusulkan satu lagi kelompok bahasa yang mungkin dapat ditambahkan menjadi kelompok bahasa (E), yaitu kelompok bahasa dengan kepemilikan adjektiva yang memungkinkan berterima atas properti gramatikal verba, namun tidak berterima atas properti gramatikal nomina, akan tetapi terinfleksi aturan sintaksis nomina berupa aturan gender dan penanda jumlah. Berdasarkan usulan tersebut, kelompok bahasa versi Dixon diusulkan untuk ditambahkan, sehingga pengelompokan bahasa dimaksud menjadi :
A. Adjektiva yang menunjukkan properti gramatikal yang sama dengan verba

B. Adjektiva yang menunjukkan properti gramatikal yang sama dengan nomina

C. Adjektiva yang menunjukkan properti gramatikal yang sama dengan nomina,namun menjalankan fungsi gramatikal yang sama dengan verba.

D. Adjektiva yang mempunyai properti gramatikal yang berbeda dari verba dan nomina.

E. Adjektiva yang menunjukkan properti gramatikal yang sama dengan verba, berbeda dengan properti gramatikal nomina namun terifleksi aturan sintaksis yang sama dengan nomina, berupa aturan gender dan penanda jumlah.

Dengan demikian, rumusan tipologi bahasa berdasarkan kepemilikan properti gramatikal oleh adjektivanya, diusulkan sebagai berikut (usulan ini sebagai revisi dari rumusan tipologi bahasa sebelumnya dalam tabel versi Dixon).

Tabel Rumusan Tipologi Bahasa Berdasarkan Kepemilikan Properti Gramatikal oleh Adjektiva. 


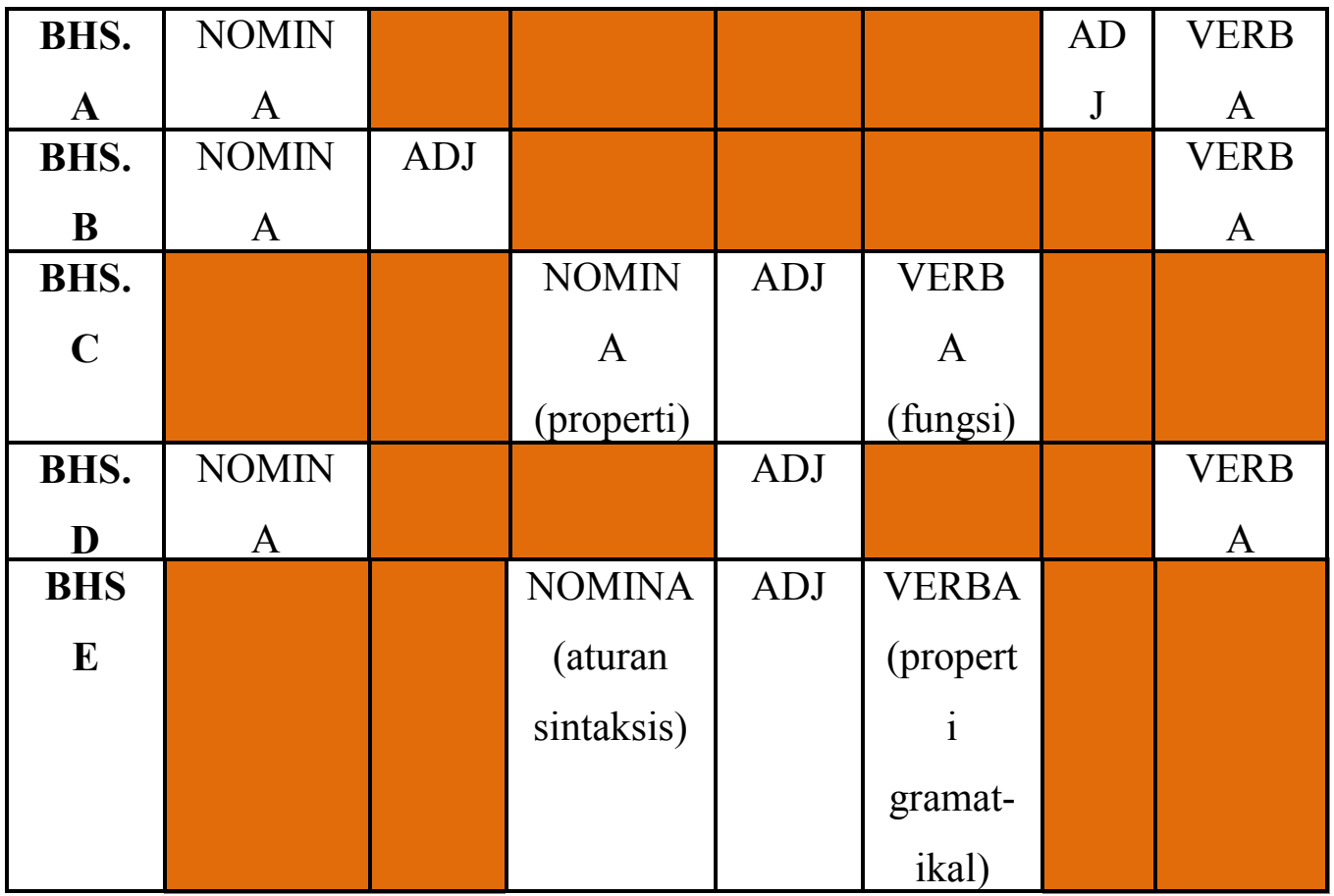

\section{SIMPULAN}

Konsentrasi tipologi linguistik tertuju pada penelitian terhadap variasi di dalam berbagai bahasa, yang menjadi dasar 'penelitian terhadap keuniversalan bahasa yang bertujuan untuk membuat batasanbatasan terhadap variasi dalam bahasa manusia. Perbedaan antara bahasa-bahasa dan dialek-dialek merupakan sebuah perbedaan yang sulit digambarkan tetapi tepat tumpuan kajian tipologi justru terletak pada hal ini untuk merumuskan keuniversalan bahasa yang tanpa pengecualian.

\section{UCAPAN TERIMAKASIH}

Penulis mengucapkan terima kasih kepada Mitra Bestari atas masukanmasukan yang telah diberikan untuk perbaikan substansi artikel saya ini.
DAFTAR PUSTAKA

Comrie, B. 1978.Ergativity. In Lehman, W.D. (ed). Syntactic Typology: studies in the phenomenology of language, 329-354. Austin: The University of Texas.

Comrie, B. 1981.Language Universals and Linguistic Typology. Oxford: Basil Blackwell.

Comrie, B. 1988a. Coreference and conjuction reduction in grammar and discourse. In Hawkins, J. (ed). Explaining Language Universals. 186-208. New York: Basil Blackwell.

Comrie, B. 1988b.Linguistic typology. In Newmeyer, F. J. (ed). Linguistics: The Cambridge Survey, Vol I. 447-467. Cambridge: Cambridge University Press.

Croft, W. 1990. Typology and Universals. Cambridge: Cambridge University Press.

Croft, W. 1991. Syntactic Categories and Grammatical Relations. Chicago: The University of Chicago Press.

Faarlund, J. T. 1988. A typology of subjects. In Hammond, M., Moravcsik, E. and Wirth, J. (eds). Studies in Syntactic Typology, 193-207. Amsterdam: Benjamins.

Foley, W. A. 1980. Toward a universal typology of the noun phrase.Studies in Language 4: 171-99.

Foley, W. and Van Valin, R. D. 1984. Information packaging in the clause. In Shopen, T (ed). Language Typology and 
Syntactic Description Vol 1, 282-364.

Cambridge: Cambridge University Press.

Greenberg, J. H. 1963. Some universals of grammar with particular reference to the order of meaningful elements. In Greenberg, J. H. (ed). Universals of Language 73-113. Cambridge: MIT Press.

Hockett, C. F. 1963. The problem of language universals. In Greenberg, J. H. (ed). Universals of Language, 1-29. Cambridge: MIT Press.

Keenan, E. L. 1987. Universal Grammar. London: Croom Helm.

Mallinson, G. and Blake, B. J. 1981. Language Typology: cross-linguistic studies on syntax. Amsterdam: North-Holland.

Ramat, P. 1987. Linguistic Typology. Berlin: Mouton de Gruyter.

Shopen, T. (ed). 1985. Language Typology and Syntactic Description. Vol I, II, III. Cambridge: Cambridge University Press. 